\title{
The conflict mitigating effects of trade in the India-Pakistan case
}

\author{
Dawood Mamoon • S. Mansoob Murshed
}

Received: 5 May 2008 / Accepted: 19 October 2009 / Published online: 7 March 2010 (C) The Author(s) 2010. This article is published with open access at Springerlink.com

\begin{abstract}
We examine whether greater inter-state trade, democracy and reduced military spending lower belligerence between India and Pakistan, beginning with a theoretical model covering the opportunity costs of conflict in terms of trade losses and security spending, as well as the costs of making concessions to rivals. Conflict between the two nations is best understood in a multivariate framework where variables such as economic performance, integration with rest of the world, bilateral trade, military expenditure, democracy orientation and population are simultaneously considered. Our empirical investigation based on time series econometrics from 1950 to 2005 suggests that reduced bilateral trade, greater military expenditure, less development expenditure, lower levels of democracy, lower growth rates and less general trade openness are all conflict enhancing. Globalization, or a greater openness to international trade with the rest of the world, is the most significant driver of a liberal peace, rather than a common democratic orientation.
\end{abstract}

Keywords Inter-state conflict and trade - Democracy and conflict · Conflict and economic development

D. Mamoon · S. M. Murshed ( $\varangle)$

Institute of Social Studies (ISS), PO Box 29776, 2502 LT,

The Hague, The Netherlands

e-mail: Murshed@iss.nl

URL: www.iss.nl

D. Mamoon

e-mail: Mamoon@iss.nl

S. M. Murshed

The Birmingham Business School, University of Birmingham,

Birmingham, Edgbaston, B15 2TT, UK

S. M. Murshed

Centre for the Study of Civil War (CSCW), PRIO, Oslo, Norway 
JEL Classification F15 $\cdot$ F51 $\cdot$ F52

\section{Introduction}

This paper examines inter-state hostility between India and Pakistan, which is arguably one of the most prominent inter-state conflicts still extant, and whose saliency is magnified by the presence of nuclear weapons. Conflict reduction is also necessary in the region to release resources for poverty reduction. We analyse some of the factors that might lead to conflict abatement between these long standing rivals, especially the role of increased international trade as a conflict mitigating factor.

Outright war is just one manifestation of the rivalry between nations; the armed peace is equally consistent with aggressiveness. India and Pakistan have had four large scale military confrontations (1948, 1965, 1971 and 1999), but otherwise spend a great deal of time in uncompromising posturing vis-à-vis each other. Central to their hostility is the territorial dispute over Kashmir. India, in particular, frequently accuses Pakistan of sponsoring terrorism in her territory. Negotiations are infrequent, but occasionally both nations make goodwill gestures, such as sending out peace buses between cities, and agree to cricket tours. Figure 1 (based on the data in Faten et al. 2004) charts the hostility levels of the two states on a scale of $0-6$. It has never been below 2, but is usually at a high level of 4 , which indicates belligerency short of outright war.

International trade allows one country to peacefully benefit from the endowment of another nation through voluntary exchange. Conflict and rivalry are symptomatic of the absence of cooperation, including lesser bilateral trade. Equally, conflict may be said to be a consequence of the lack of trade. Polachek (1997) and Polachek and Seiglie (2006) argue that wars and disputes between geographically contiguous states involve substantial losses, as more efficient geographically proximate trade is displaced. Figure 2 shows that India-Pakistan official trade (as a proportion of Pakistan's total international trade) steadily declined from nearly $20 \%$ in the early 1950 s, plummeting to almost zero after their war in 1965, and has shown some signs of recovery in the 1990s. But it is still below the levels of the 1950s, which was shortly after the

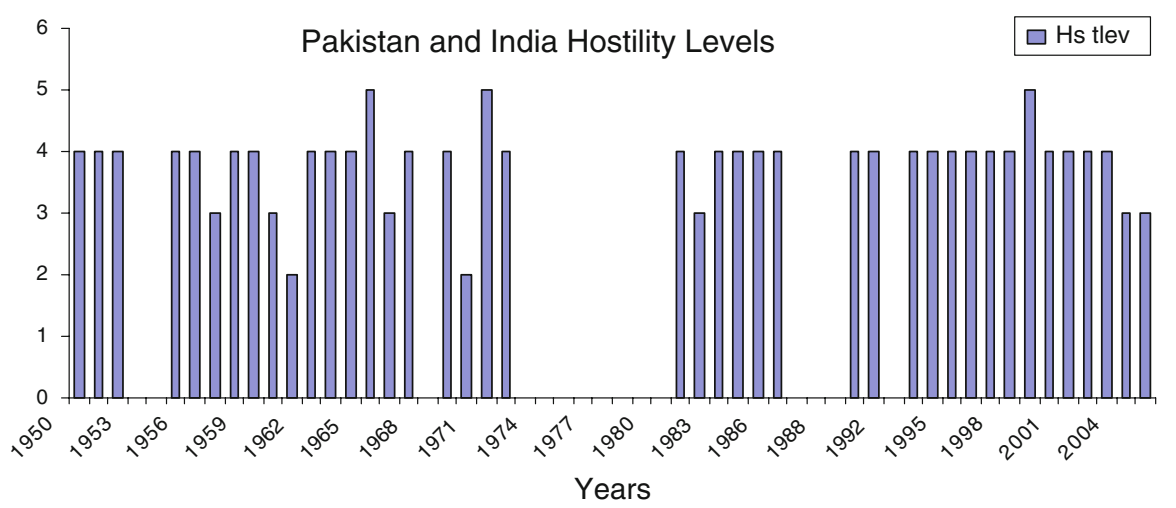

Fig. 1 Hostility levels between India and Pakistan 


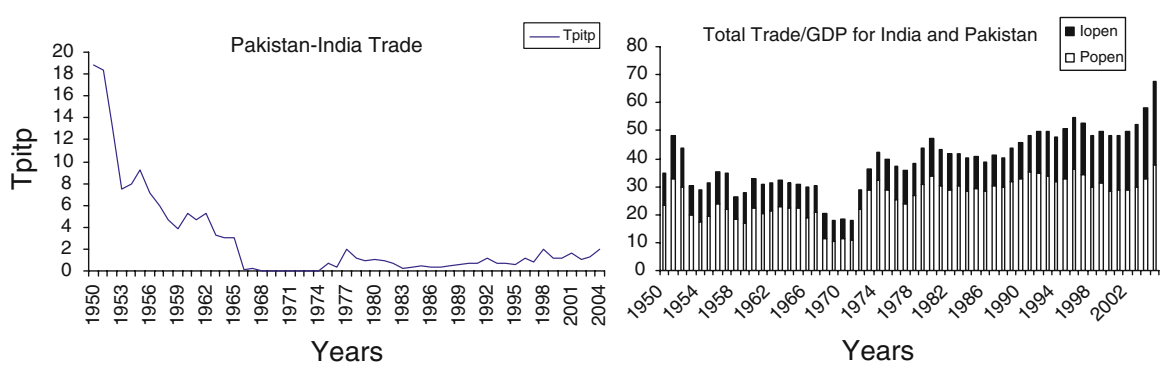

Fig. 2 Patterns in India-Pakistan trade

two nations separated. This is despite the fact that both India and Pakistan have fairly open economies at present.

In the traditional realist international relations literature, nations co-exist in a Hobbesian state of nature, where war is an opportunistic act actuated by self-interest, and unrestrained by any social contract. Peace is maintained by a balance of power. In contrast to this view are notions of the liberal peace; see Murshed (2010, chapter 7) for a review. The liberal peace may then be sub-divided into two strands: the first among which is its idealist variant, sometimes referred to as the democratic peace. The idea is that democracies will not fight each other because they share cultural norms that militate against forceful dispute resolution, or alternatively the checks and balances that characterise political processes in advanced democracies restrain violence. Put simply, the idea is that established democracies do not go to war with each other, but cooperate instead. The intellectual basis for this argument is traced back to Immanuel Kant (1795) work on the Perpetual Peace, where a like mindedness referred to as cosmopolitanism would prevent outright war between republics; a tendency that could be reinforced by commercial interdependence.

The alternative notion of the liberal peace ${ }^{1}$ argues that it is against the economic self-interest of nations to go to war with each other as it seriously disrupts mutually beneficial international trade. ${ }^{2}$ The trouble with the pacific interpretation of international trade is that during the two world wars of the 20th century, highly interdependent economies went to total war with each other. While all analysts agree that war impedes trade, the realist view is that countries may choose to disrupt their potential enemy's gains from trade by ceasing trade with them, even if this means hostilities. Even if there are losses to the aggregate economy from war or diminished trade, some groups may gain, and these groups may be the more politically influential. For example, Kim and Rousseau (2005) find that conflict diminishes economic interdependence, but not the other way around, providing only partial support for the opportunity cost of trade liberal peace theory.

\footnotetext{
1 Theories of the liberal peace may be traced back to the Baron de Montesquieu's, Spirit of the Laws (1748), where he states that commerce tends to promote peace between nations; mutual self-interest precludes war; trade also softens attitudes of peoples towards each other.

2 Sir Normal Angell, winner of the 1933 Nobel peace price and former editor of Foreign Affairs, in his great book The Great Illusion, asserted that nations could never enrich themselves through war, and even a victorious nation would come off economically worse from a war; see Angell-Lane (1910).
} 
Dorussen and Ward (2010) rehabilitate the role of trade in producing peace through a novel channel. They argue that trade has important indirect effects over and above the interdependence induced by bilateral trade. Increased trade generally, may do little to mollify war-like tendencies between a pair of countries, but if each of these countries interacts considerably with third countries, it will be not in their interests to go to war with each other, as it disrupts other links and networks. In other words, any two countries are unlikely to go to war with each other if there trade with the rest of the world is disrupted even when their bilateral trade dependence is low. Among other updates to the liberal peace theory based on economic interdependence is the 'capitalist' peace notion of Gartzke (2007), where the notion of interdependence is nuanced, and the saliency of international trade in goods and services de-emphasized. The nature of advanced capitalism makes territorial disputes over resources less likely as the market mechanism allows easier access to these. The nature of production makes the output of more sophisticated goods and services increasingly reliant on 'ideas' that are research and development intensive, and skilled personnel can be acquired through more open global labour markets. Moreover, the disruption to integrated financial markets makes war less likely between countries caught up in that web of interdependence. McDonald (2004) demonstrates that it is not just the trade intensity between nations, but a commitment to the policy of free trade, that may promote the liberal peace as it serves to dampen domestic protectionist and pro-war interests, as will be demonstrated by our analysis.

In summary, the liberal peace ideas may rest upon a tripod (Gleditsch 2008) with economic inter-dependence, democracy and common membership of international organisations (the UN, NATO and the European union, for example) preventing inter-state war. With regard to the relative contribution of democracy vis-à-vis trade, Polachek (1997) presents empirical evidence suggesting that advanced democracies cooperate, not because of their similar political systems, but due to their vast and multiply intersecting economic interdependence.

Reverting back to the India-Pakistan example, we have noted that there bilateral trade is very limited despite the fact that they are neighbours. What of their political orientation? Here, too there is divergence. The Polity score gives us an average score of democracy and autocracy ranging from 10 to -10 , acting as an indicator of the overall political system. India has always had one of the highest democracy scores in the developing world (scoring 7-9), whereas Pakistan's experience with democracy fluctuates, with high autocracy scores associated with military coups in 1958, 1969, 1977 and 1999. Figure 3 indicates that military expenditures tend to move inversely with development (education) expenditure, providing prima facie evidence that large military expenditure crowds out development. In fact, these two countries have among the highest military burdens in the world outside the Middle East (World Development Indicators 2006).

The opportunity costs of conflict could rise when countries move to higher stages of economic development as they have more to lose from conflict, and have more resources to negotiate peaceful settlements. The 1990s is considered to be a golden decade for India as GDP growth rates on average the Indian economy grew at 5-6\% annually. Pakistan, too, has seen a growth spurt up to 2007. If anything, conflict between the two nations can be best understood in a multivariate framework. We examine whether greater inter-state trade, democracy and reduced military spending lowers 


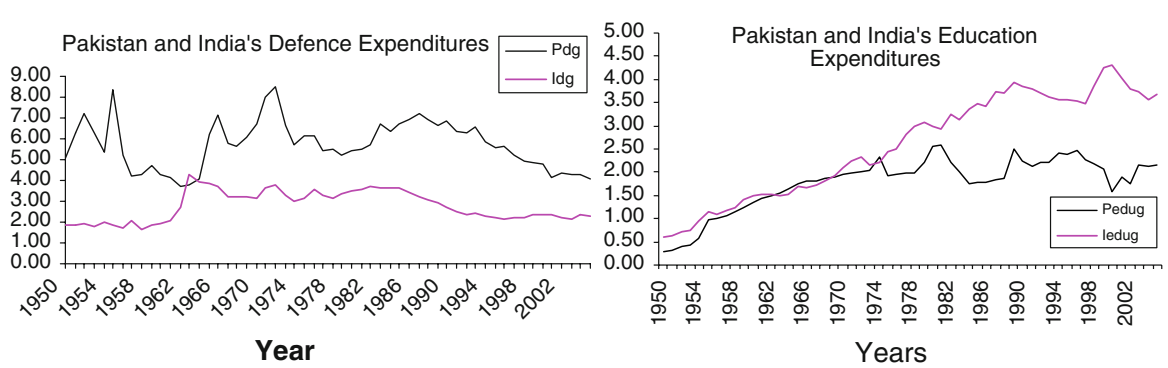

Fig. 3 Conflict, development and democracy trends in India-Pakistan

belligerence between India and Pakistan in a time series framework, between 1950 and 2005 in most cases. The rest of the paper is organised as follows: Sect. 2 contains the theoretical model, the empirical analysis is presented in Sect. 3, where the relevant variables and processes (economic performance, integration with rest of the world, bilateral trade, military expenditure, democracy and population) are simultaneously taken into account, finally Sect. 4 concludes.

\section{Theoretical model}

This section consists of two parts: the first deals with the costs of belligerent behaviour in a single country context where the losses are displaced trade and the crowding out effects of defence expenditure; the second looks at the costs of peaceful behaviour where the disutility of making concessions to an adversary is modelled in a two country setting. The situations we model either pertain to limited warfare, with negligible effects on national endowments, or alternatively we could be said to model the costs of an armed peace associated with large security and military establishments. In many ways, conflict has similar effects as other forms of trade wars.

\subsection{Costs of war}

We begin with a single country's decision making with regard to belligerence, based on Polachek (1997). The welfare of either country $(U)$ depends upon consumption $(E)$, and security $(S)$, entering the utility function in a separable fashion:

$$
U=u(E, S)
$$

Where:

$$
E=c Q-X+M-T
$$

$Q$ is the total endowment of the country where a proportion $c$ is devoted to private and public non-military consumption and investment; a fraction $1-c$ to a public good covering security or military expenditure. $X$ and $M$ denote exports and imports to the rival country, and $T$ represents trade (exports minus imports) with the rest of the world. $\theta$ is the price of the exportable and the price of the importable is the numeraire good, 
normalised at unity. There is also a balance of trade constraint; the value of exports must equal imports:

$$
\theta X(S)-M+T=0, \ldots X_{s}<0
$$

Following Polachek (1997) let us postulate that conflict disrupts trade. Specifically, it lowers exports, but unlike in Polachek's model both countries are hostile towards each other, and not just one country (described as the actor) against a passive target. So, in our model, both countries exports to each other will decline, along with ambiguous effects on the terms of trade. The country whose goods are demanded more elastically will experience the negative terms of trade effect. Nevertheless, exports displaced by conflict are a loss, as they represent foregone trade, especially in the context of neighbours who might be expected to trade substantially in peaceful circumstances. Substituting (3) as a constraint and (2) into (1) allows us to write a Lagrangian function $(L)$, where $\lambda$ indicates the Lagrange multiplier:

$$
L=u(c Q-X+M-T ; S)+\lambda[\theta X(S)-M+T]-C(S)
$$

The function $C$ represents the distortionary (taxation and crowding out) costs of security expenditure, which rises with $S$, so that the partial derivative is positive. This is an additional cost associated with security spending, absent in Polachek (1997) model. The first order condition with respect to $S$ is:

$$
u_{s}=-\lambda X_{s}+C_{s} \cdots u_{s}, C_{s}>0, X_{s}<0
$$

In Eq. (5) the marginal utility of security $\left(u_{s}\right)$ is equated to its marginal costs. The latter (on the right-hand side of (5)) is comprised of the trade disruption due to conflict, and the cost of diverting resources to military and security expenditure. This, last effect, is absent from the Polachek models. The cost of conflict is not just confined to displaced trade, but it also has a distortionary resource cost because of security expenditure, either because of distortionary taxation or due to the crowding out effect on other forms of investment, including government spending on health and education; see Deger and Sen (1990). Note, that security expenditure and benefits derived from confronting one's enemy does yield positive utility, but comes at a price. There is, therefore, an additional cost of belligerent behaviour over and above losses from trade displacement, and is likely to be substantial because it detracts from poverty reduction directly.

\subsection{Costs of peace}

If peace is Pareto optimal, why don't countries favour it? In this section we model the costs of peace, which include psychic non-pecuniary costs of making concessions to one's adversaries. Additionally, we try to demonstrate how increased globalization and democratisation can help to reduce conflict by lowering the cost of making 
concessions to one's neighbours. To analyse these factors we require a two country expected utility model of non-cooperative strategic interaction.

The two countries: India and Pakistan are indexed by subscripts $I$ for India and $P$ for Pakistan. There are two states of nature, denoted by superscripts: one more peaceful or dovish $(D)$, and the other associated with greater hawkishness $(H)$. Their probabilities are defined as $\pi$ and $1-\pi$, respectively. The probability of either state is in turn affected by a actions and efforts; $(a)$ for India and (e) for Pakistan. These are also the strategic variables employed by the two sides to the conflict. We postulate that the probability of the peaceful state $\pi$ rises with the input of action and effort by the two sides, but at diminishing rates. One can imagine a range of activities by one or both sides if they wish to promote peace, including a greater willingness to compromise, reduce military expenditure, devoting more resources to peaceful economic development, or a greater willingness to respond to calls for peace by third-parties such as the UN and the United States.

Actions and efforts to seek peace entail costs for each party. The costs of actions to promote peace could take a variety of forms, but, above all, there is the loss of face to either party's hawkish domestic political constituencies, including the military establishment. Increased globalization may, however, augment the stock of rhetoric available to politicians who wish to push their 'peace' agenda through the political process. Secondly, and in a more palpable sense, increased international trade and the growth it brings may provide the additional resources to buy off domestic 'war' lobbies. A more democratic government, following military rule, may similarly use its mandate from the people to justify greater peace and reduced military expenditure.

The expected utility of India is given by

$$
U_{I}=\pi(a, e) U_{I}^{D}\left(E_{I}^{D}+S_{I}^{D}\right)+(1-\pi)(a, e) U_{I}^{H}\left(E_{I}^{H}+S_{I}^{H}\right)-Z(a(T))
$$

Where $U_{I}^{D}$ and $U_{I}^{H}$ denote utilities or pay-offs in dovish and hawkish states respectively, weighted by the probabilities of the two states. $E_{I}^{D}+S_{I}^{D}, E_{I}^{H}+S_{I}^{H}$ indicate the exogenous pair of payoffs from consumption and security expenditure respectively, in the less belligerent and more belligerent states, respectively. The difference is that in dovish state security spending is lower and private consumption higher than in the hawkish state. There will also be more trade between the two countries. Most importantly, the dovish state of nature will imply greater poverty reduction. $Z$ is the cost function of undertaking the action, $a$. Action, $a$, increases the probability of peace, $\pi$, however, undertaking it entails a cost, as described above. $T$ indicates greater globalization (more trade with the rest of the world), and this is postulated to reduce the cost of making peace via the cost function $(Z)$ as discussed above, $Z_{a 1}<0 .{ }^{3}$ Also, $\pi_{a}>0$, but $\pi_{a a}<0$; there are diminishing returns to these actions. However, both $Z_{a}>0$ and $Z_{a a}>0$.

Turning to Pakistan, we symmetrically have

$$
U_{P}=\pi(a, e) U_{P}^{D}\left(E_{P}^{D}+S_{P}^{D}\right)+(1-\pi)(a, e) U_{I}^{H}\left(E_{P}^{H}+S_{P}^{H}\right)-L(e(T, P))
$$

\footnotetext{
3 Increased globalization is unlikely to directly affect the marginal productivity of actions or efforts $(a, e)$ that raise the probability of peace $(\pi)$.
} 
$L$ is the cost of effort, $e$, which increases the probability of peace, $\pi$. As with India, greater globalization lowers the marginal cost of making peaceful concessions, but so does a hybrid concept called increased democratisation $(P)$ for Pakistan only given the nature of swings there between democratically elected governments and military rule; $L_{e 1}$ and $L_{e 2}<0$. Also, $\pi_{e}>0$, but $\pi_{e e}<0, L_{e}>0$, and $L_{e e}>0$.

In the non-cooperative or Cournot-Nash game played by the two sides both sides move simultaneously. Each side, therefore, maximises its own utility function with respect to its own choice variable. For India, it implies maximising utility, Eq. (6), with respect to $a$ as shown by

$$
\pi_{a}\left[U_{I}^{D}(\cdot)-U_{I}^{H}(\cdot)\right]=Z_{a}
$$

Pakistan maximises Eq. (7) with respect to $e$

$$
\pi_{e}\left[U_{P}^{D}(\cdot)-U_{P}^{H}(\cdot)\right]=L_{e}
$$

Note that in Eqs. (8) and (9) each side will equate its marginal benefit from exercising their own strategic choice to the corresponding marginal cost. Each side's strategic choices will depend on the first order conditions given in Eqs. (8) and (9), along with a fixed conjecture about the opposition's strategic choice. These lead to the (linear) reaction functions for both sides, obtained by totally differentiating Eqs. (8) and (9) with respect to $a$ and $e$. For India this is indicated by

$$
\frac{d e}{d a / R_{I}}=\frac{Z_{a a}+\pi_{a a}\left[U_{I}^{H}(\cdot)-U_{I}^{D}(\cdot)\right]}{\pi_{a e}\left[U_{I}^{D}(\cdot)-U_{I}^{H}(\cdot)\right]} \frac{\geq}{\leq} \ldots 0 \ldots i f \cdots \pi_{a e} \frac{\geq_{\leq}}{\leq} 0
$$

and for Pakistan by

$$
\frac{d e}{d a / R_{P}}=\frac{\pi_{a e}\left[U_{P}^{D}(\cdot)-U_{P}^{H}(\cdot)\right]}{L_{e e}+\pi_{e e}\left[U_{P}^{H}(\cdot)-U_{P}^{D}(\cdot)\right]} \underset{\leq}{\leq} \ldots 0 \ldots i f \ldots \pi_{a e} \sum_{\leq} 0
$$

Note that $\pi_{a e}=\pi_{e a}$ by symmetry.

The reaction functions are positively sloped if $\pi_{a e}>0$, implying that the two strategies are complements. This is the standard assumption in the literature on conflict. In our model, however, we postulate that $\pi_{a e}<0$, the choice variables are strategic substitutes, and the reaction functions slope downwards (Fig. 4). This can only occur because the strategy space is defined in terms of peace. Thus, if one side behaves more peacefully it increases the utility of both parties and the other side may free ride on this action by not bringing about a corresponding increase in their action. This is particularly relevant in the case of asymmetric bilateral power, as India's economic and military power is vastly more than Pakistan's.

In Fig. 4, two non-cooperative equilibria are illustrated by points $N$ and $C$, respectively. Point $C$ is more cooperative and peaceful with greater inter-country trade and poverty reduction. A shift from $N$ to $C$ can occur because of greater globalisation (rise in $T$ ) because of, say, the establishment of a free trade area, and increased international 


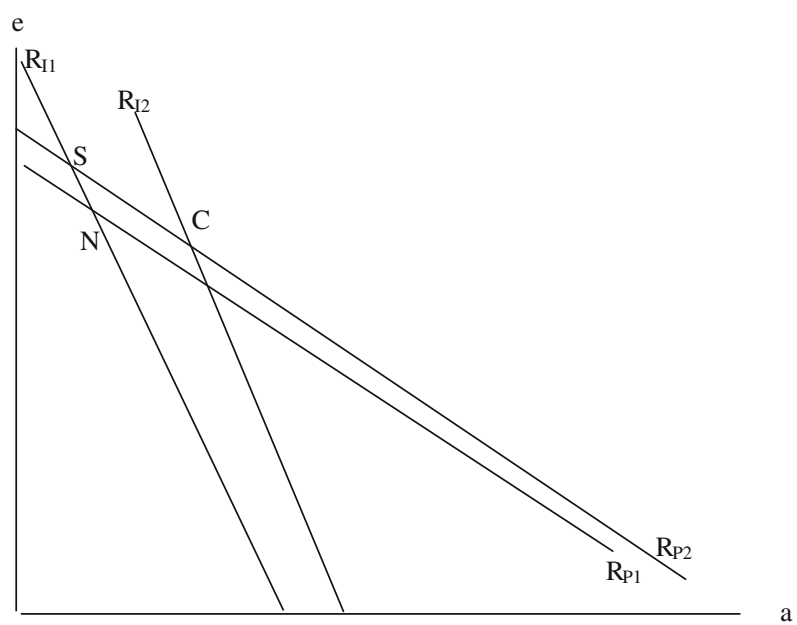

Fig. 4 Reaction functions of India and Pakistan

(not necessarily just bilateral) trade lowers the marginal cost of peaceful behaviour $\left(Z_{a 1}, L_{e 1}<0\right)$. Analytically this means a change in the first-order conditions for both India:

$$
\pi_{a}\left[U_{I}^{D}(\cdot)-U_{I}^{H}(\cdot)\right]=Z_{a 1} d T
$$

and, for Pakistan

$$
\pi_{e}\left[U_{P}^{D}(\cdot)-U_{P}^{H}(\cdot)\right]=L_{e 1} d T
$$

This pertains to the economic liberal peace. Alternatively, there could be a rise in the exogenous pay-offs in terms of consumption expenditure $(E)$ in (8) and (9) above, leading to the same outcome in Fig. 4.

The costs of peaceful actions may be easier to bear when countries (in this case only Pakistan) are more democratic, as there may be a mandate from the people to engage in more poverty reduction, greater social sector spending and lower military expenditure. This corresponds to the democratic version of the liberal peace, causing the first order condition for Pakistan to become:

$$
\pi_{e}\left[U_{P}^{D}(\cdot)-U_{P}^{H}(\cdot)\right]=L_{e 2} d P
$$

This causes Pakistan's reaction function to shift outwards along India's, with a new equilibrium at point $S$. Note, however, in the new equilibrium (point $S$ ) India has effectively passed on some of the burden of adjustment to Pakistan. In fact, the level of effort exercised by Pakistan is greater than even in the more cooperative solution $(C)$, but not India's. We could argue that India is free riding on Pakistan. In recent years more international pressure has been exerted on Pakistan to make unilateral concessions towards India since 2001. 


\section{Empirical analysis}

\subsection{Hypotheses}

$H_{1}$ : Greater bilateral inter-state commerce between the two countries, as well as greater multilateral trade with third countries lowers various forms of bilateral inter-state conflict. This corresponds to the economic version of the liberal peace. This hypothesis follows from our theoretical discussion, specifically the first order conditions in $\left(8^{\prime}\right)$ and $\left(9^{\prime}\right)$, and in inversely from the right-hand side of (5).

$\mathrm{H}_{2}$ : More military spending as a result of increased insecurity raises conflict. The hegemonic power, however, may have internal conflict (India has many civil wars) and other neighbours to militarily confront. The marginal utility of security spending rises in (5), as well as in (8) and (9).

$\mathrm{H}_{3}$ : Development expenditure (such as public spending on education) should lower conflict, because of economic growth which enables more consumption in Eqs. (4) to (9). This is also related to the increased democratisation hypothesis, below.

$H_{4}$ : GDP growth will decrease inter-state conflict; there is more to lose from war. This raises the utility from consumption in (4), (6) through to (9).

$H_{5}$ : Increases in dyadic democracy scores will lead to less conflict, related to the notion of the democratic version of the liberal peace. Increased democracy may lower the cost of concessions and compromise with former enemies, as in $\left(9^{\prime \prime}\right)$ above.

\subsection{Empirical results}

There are various data sources on inter-state conflict, see Murshed and Mamoon (2007). In this paper we report results using the Uppsala Conflict Data Project (UCDP) with the collaboration of the International Peace Research Institute, Oslo (PRIO) and is collected on an annual basis and covers the full post-World War II period, 19462003, see Harbom et al. (2006). Military expenditures can reflect hostility, as well as deterrence (Polachek and Seiglie 2006). In the India-Pakistan case, we would like to examine how each country's military expenditure/ military burden affects the dispute. Pakistan's spending on military expenditure as a proportion of GDP is higher than India's. We also look at the proportion of military personnel to the overall population. This might reflect the extent of militarization in a society. To capture democracy levels for India and Pakistan, we turn to the Polity IV Project hosted by Center of International Development and Conflict Management (CIDCM). Polity IV computes a combined polity score by subtracting autocracy scores from the democracy scores for the corresponding year. The value of this Polity score ranges from -10 to 10 , where -10 denotes the highest autocracy level, and 10 the maximum democracy score. Although India always takes a high positive value of 7 or above, Pakistan frequently takes on negative values. We construct a dyadic variable of democracy for both countries by combining (multiplying) their Polity scores, following Polachek and Seiglie (2006). 
We add 10 to each countries polity series to make the negative Polity values positive so that our combined democracy score may capture the variations in the democratization process only on a positive scale. The dyadic democracy variable shows values as low as 50 on the scale of 0 to 400 when there are high levels of political dissimilarities between Pakistan (dictatorship) and India (democracy), and as high as 350 when both countries are governed by democracies (see Fig. 5). A full data description is presented in the appendix.

Any simple least square regression analysis may lead to spurious results due to the endogeneity problems among our variables (from trade, military expenditure and growth to conflict and vice-versa). We need to utilize a simultaneous equation model where potential endogeneities between various variables are addressed. In Murshed and Mamoon (2007), based on our time series data, we ran a Vector Autoregressive model (VAR) which is an extension of univariate autoregressive (AR) models to capture the evolution and the interdependencies between our multiple time series (Sims 1980). These results were based on dyadic variables and we found that trade with the rest of the world was the major factor in reducing India-Pakistan conflict. In other words, general globalization was most important in lowering India-Pakistan tensions, compared to bilateral trade. This is not surprising, as these two countries being quite poor are more likely to trade with the rest of the world compared to each other. Secondly, a common democratic orientation is secondary to globalization in mitigating conflict between the two nations (as indicated earlier, this applies mainly to Pakistan, as India is a steady democracy whereas Pakistan oscillitates between military rule and elected governments). Thus, we found greater support for the economic version of the liberal peace relative to the purely democratic peace. Interestingly when we ran Granger (1969) causality tests we found reverse causality between conflict and bilateral trade, as well as militarization and education expenditure. Thus, increased trade not only reduces conflict, but conflict also lowers bilateral trade. A similar argument can be applied to militarization and education expenditure, as increased threat perceptions also raise military expenditure and lower development spending.

In this paper we analyze country specific, rather than dyadic, effects in order to investigate in detail the potential of each country's trade levels, military burden,

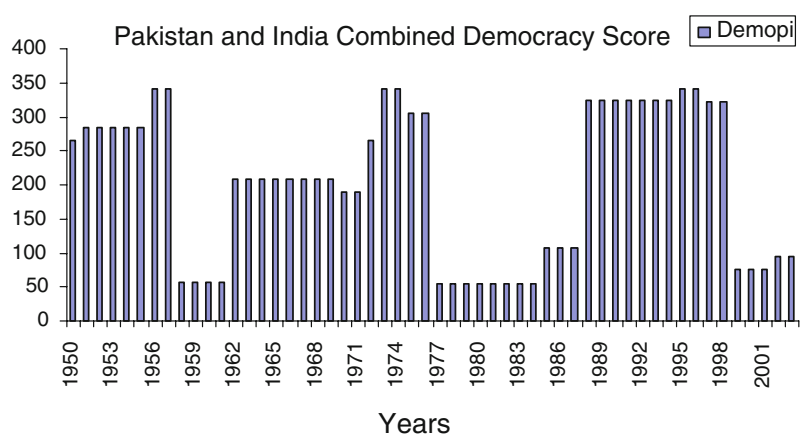

Fig. 5 Dyadic democracy scores for Pakistan and India 
development expenditure and economic performance in enhancing peace and mitigating conflict. For Pakistan, we use Pakistan's trade share with rest of the world (Popen), Pakistan's total exports to GDP ratio (Pexpg) and Pakistan's imports to GDP ratio (Pimpg) as proxies for Pakistan's multilateral trade. Pakistan's exports to India $(P x i)$ are a proxy for bilateral trade. Pakistan's defence expenditure as a percentage of its GDP $(P d g)$ is a proxy for the military burden, and Pedug is Pakistan's education expenditure as a percentage of its GDP. Similarly for India, we employ 3 proxies of multilateral trade namely Iopen, Iexpg and Iimpg, 1 proxy for bilateral trade (Ixp), 1 proxy for military burden $(I d g)$ and 1 proxy for education expenditure (Iedug). We do not use separate Polity scores for India and Pakistan, as any changes in combined democracy scores are due to Pakistan. Before we carry out our econometric analysis, we undertook the stationary test. Note that our independent variables are time series in nature, and thus may have autocorrelation. Achieving stationarity in such series may be difficult.

We ran unit root tests on the above variables and find that the unit root is only solved at first differences, as shown by Table 1 . Since at levels, nearly all variables have unit roots, there should be at least one co-integrating relationship for our analysis to move forward. In other words, we cannot use unrestricted VAR analysis but need to undertake Vector Error Correction Methodology (VECM) which is only a restricted VAR, where we first find the presence of the number of co-integration equations in each VECM specification and then run the regression analysis. VECM also allows us to have a rich set of information among variables including their short and longterm adjustment dynamics and thus provides a more comprehensive insight into the relationship among variables compared to an unrestricted VAR.

The three reduced form VECM equations for Conflict are as follows:

$$
\begin{aligned}
\operatorname{Conf}_{1 t}= & \alpha_{1}\left(\beta_{1, t-i} \operatorname{Conf}_{t-i}+\beta_{2, t-i} \text { Ptr }_{t-i}+\beta_{3, t-i} \text { Itr }_{t-i}+\beta_{4, t-i} P d g_{t-i}\right. \\
& \left.+\beta_{5, t-i} I_{d g_{t-i}}+\beta_{6, t-i} \text { Demo }_{t}\right)+\sum_{y=1}^{6} C_{y a, t-i}+\mathrm{E}_{1 t}
\end{aligned}
$$

$\operatorname{Conf}_{2 t}=\alpha_{2}\left(\beta_{7, t-i} \operatorname{Conf}_{t-i}+\beta_{8, t-i}\right.$ Pedu $_{t-i}+\beta_{9, t-i}$ Iedu $_{t-i}+\beta_{10, t-i} P d g_{t-i}$

$$
\left.+\beta_{11, t-i} I d g_{t-i}+\beta_{12, t-i} \text { Demo }_{t}\right)+\sum_{y=1}^{6} C_{y b, t-i}+\mathrm{E}_{2 t}
$$

$\operatorname{Conf}_{3 t}=\alpha_{3}\left(\beta_{13, t-i} \operatorname{Conf}_{t-i}+\beta_{14, t-i} \operatorname{Pgpc}_{t-i}+\beta_{15, t-i} \operatorname{Igpc}_{t-i}+\beta_{16, t-i} \operatorname{Pdg}_{t-i}\right.$

$$
\left.+\beta_{17, t-i} I_{d g_{t-i}}+\beta_{18, t-i} \text { Demo }_{t}\right)+\sum_{y=1}^{6} C_{y c, t-i}+\mathrm{E}_{3 t}
$$

Here, $\beta$ s show the co-integration relationship for each variable under investigation for each equation, and the $\alpha s$ show the adjustment parameters. $C s$ are the constant terms for each six variables on the right hand side of each VECM equation, and the E/s are the respective error terms. As mentioned, the general openness indicator, total export shares, total import shares and exports to the other country of conflict for both India 
Table 1 Augmented Dickey Fuller test

$*$, ** and $* * *$ shows significance at 1,5 and $10 \%$ level

\begin{tabular}{llll}
\hline Variables & Lag length & With intercept & With intercept and trend \\
\hline$\Delta$ Fatal & 1 & $-0.875^{*}$ & $-0.929^{*}$ \\
$\Delta$ Popen & 1 & $-0.977^{*}$ & $-0.984^{*}$ \\
$\Delta$ Iopen & 1 & $-1.192^{*}$ & $-1.495^{*}$ \\
$\Delta$ Pexpg & 1 & $-0.937^{*}$ & $-0.965^{*}$ \\
$\Delta$ Iexpg & 1 & $-0.940^{*}$ & $-1.257^{*}$ \\
$\Delta$ Pimpg & 1 & $-1.125^{*}$ & $-1.121^{*}$ \\
\hline Iimpg & 1 & $-1.321^{*}$ & -1.449 \\
$\Delta$ Pxi & 1 & $-1.692^{*}$ & $-1.702^{*}$ \\
$\Delta$ Ixp & 1 & $-1.971^{*}$ & $-2.328^{*}$ \\
$\Delta$ Pedu & 1 & -0.946 & $-1.025^{*}$ \\
$\Delta$ Iedu & 1 & $-0.841^{*}$ & $-0.879^{*}$ \\
$\Delta$ Pgpc & 1 & $-1.992^{*}$ & $-1.995^{*}$ \\
$\Delta$ Igpc & 1 & $-2.292^{*}$ & $-2.293^{*}$ \\
$\Delta$ Pdg & 1 & $-1.421^{*}$ & $-1.441^{*}$ \\
$\Delta$ Idg & 1 & $-0.899^{*}$ & $-0.877^{*}$ \\
$\Delta$ Pmilpop & 1 & $-1.289^{*}$ & $-1.292^{*}$ \\
$\Delta$ Imilpop & 1 & $-0.756^{*}$ & $-0.766^{*}$ \\
$\Delta$ Demopi & 1 & $-0.982^{*}$ & $-0.982^{*}$ \\
\hline & & &
\end{tabular}

and Pakistan are utilized as 4 separate single country proxies of trade. Thus there are 4 separate specifications for Eq. (12). Equation (13) employs education and Eq. (14) employs per capita growth rates to capture development expenditure and level of economic development for India and Pakistan, respectively while defense and democracy proxies are common regressors for all specifications. Fatal, which is our dependent variable, captures severity of conflict. The total number of VECM specifications rise to 6 .

The results for the VECM equations are presented in Table 2. The lag length for each VEC equation is (1), based on final prediction error (FPE), Akaike's information criterion (AIC), Schwarz's Bayesian information criterion (SBIC) and the Hannan and Quinn information criterion (HQIC). There is one co-integrating equation in each VECM, confirming the robustness of the model specification. Note, that optimal value of conflict is zero in the long run, meaning that our conflict measure, Fatal takes the value of 0 .

The results for VECM 1 show that Fatal takes a negative value, and Popen and Iopen positive values. This means that in the short-term both Pakistan and Indian trade shares are negatively related with Fatal. However, only Indian trade is significant enough to exert a negative pressure on hostilities in the short-term adjustment period. In the long run both Pakistan's and Indian trade shares with rest of the world will adjust by moving in opposite directions. In the long run Pakistan would witness a rise in its trade with the outside world and Indian trade would decline to its steady-state level. The long-term net result on the trade share of both countries is expected to be positive as trade would be at higher levels with 


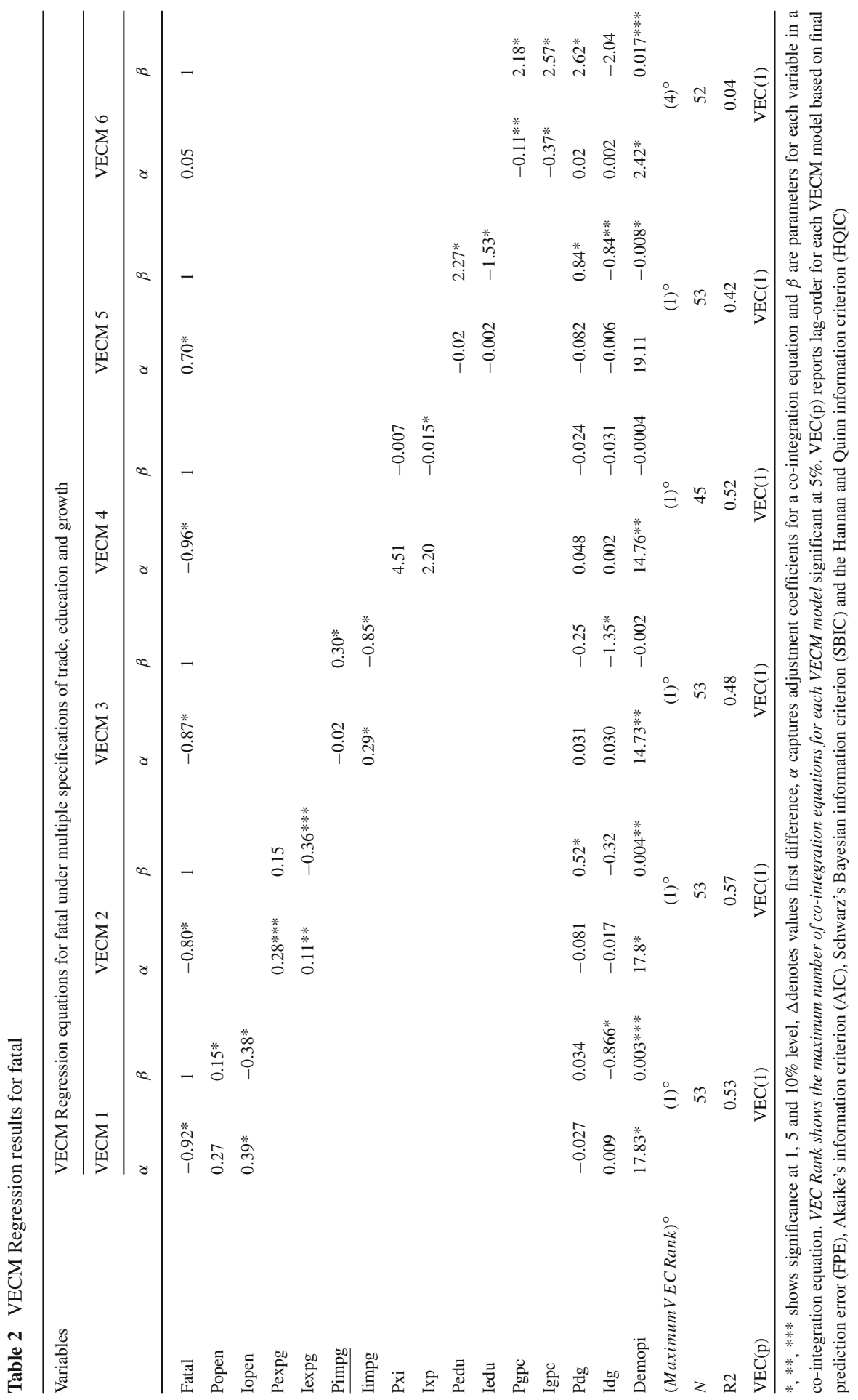


peace. The long-term rise in Pakistan's trade shares in order to adjust to a fall in hostility levels also mean that the negative effects of India-Pakistan conflict have thwarted Pakistan's capacity to trade in international markets more than in India' case. Results on VECM 2 suggest that in short-term both exports by India and Pakistan would rise to adjust to any fall in conflict. However, in the long run Pakistani exports would remain unchanged, whereas Indian exports will adjust downwards. Similar short-term adjustment dynamics for imports are observed for India in VECM 3. However in the long run Pakistan's imports would rise as conflict moves to its minimally optimal value of 0 , whereas imports by India will adjust downwards. The above discussion suggest that Pakistan's trading capability has been seriously hampered by the conflict between both nations despite the fact Pakistan has been historically the more open economy when compared to India. As far as Indian trade with the outside world is concerned, in the short-term it is destined to rise further especially if hostilities with Pakistan abate. However, the long run trade share would adjust downwards unless India follows a more open trade policy and reduces its tariffs to levels similar to Pakistan.

Bilateral trade would also respond to increased peace as shown by the results of VECM 4. In the short-term there is a sign of increase in bilateral trade between India and Pakistan, but the increase is not significant meaning trade between India and Pakistan would remain low. However, in the long run Indian exports to Pakistan would decline to reach a steady-state level. Some in Pakistan fear that peace initiatives like reducing tariffs for Indian goods would mean greater dependency on Indian produce. Taking into account the historically high hostility levels between two countries, any peace initiative or confidence building measure which leads to greater market access for India is viewed with scepticism in Pakistan, as many fear that dependence on India may expose Pakistan to unnecessary pressures from India, leaving her vulnerable to one sided solutions to the Kashmir dispute. Our results show that in the long run the dependency on Indian cheap goods would actually decline, and both countries would end up being equal trading partners. Thus more bilateral trade, far from creating any power imbalance between India and Pakistan, would equally distribute the gains. Pakistan may fulfil its import needs more from other developing countries such as China. The results for VECM 5 suggest that education expenditure would increase in the short-term to reduce conflict, and as conflict falls to its optimal level, Pakistan would be able to simultaneously devote greater resources to its education sector. High growth rates also adjust positively to decrease hostility levels and in the long run as the hostilities fall, both countries also witness a strong positive effect on their growth rates. This means that peace would put India and especially Pakistan on higher growth paths on a sustainable basis.

In order to further check the conclusions drawn from our VECM results in Table 2, we generated 6 different forecast schedules from 6 co-integrating VECMs as a simulation exercise to predict how conflict would be affected by changes in its determinants. Note that the data on Fatal are only up to 2002. Thus the one year forecasts are generated for Fatal for 2003 period. Figure 6 shows the forecast graphs. Graph 1a, $1 \mathrm{~b}$ and 1c suggest that if military expenditures in both countries would remain at its current high levels, along with trade with the outside world at their 2002 levels, a slight deterioration in democracy scores will have a significant effect on the rise in hostility. 

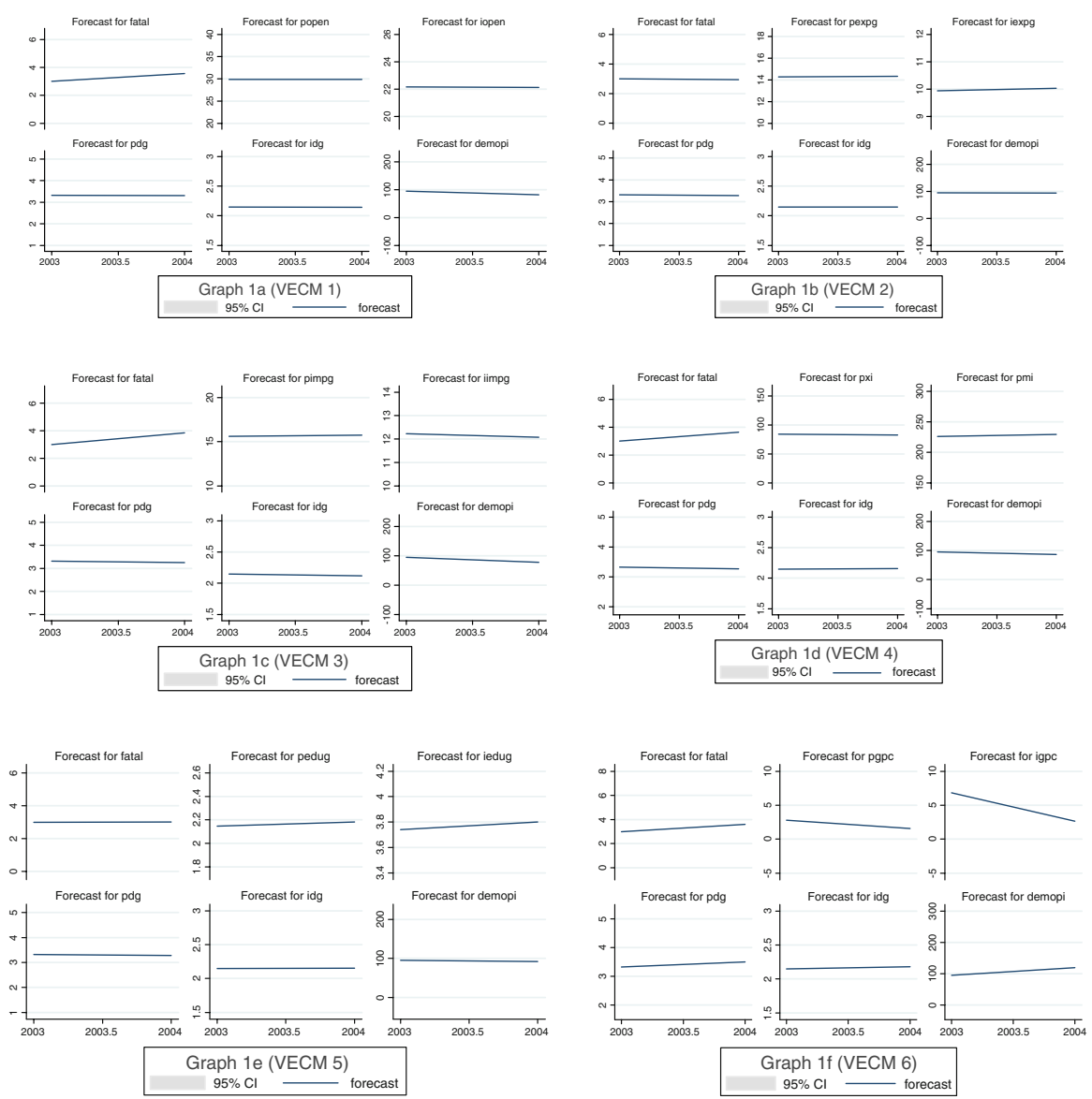

Fig. 6 Forecasting simulations based on VECMs for fatal

However, if India is able to export or import more, this would at least put a check on any rise in the severity of conflict and hostilities would adjust to some average level. Any decline in Indian trade will enhance hostilities. The current low levels of bilateral trade between Pakistan and India is conflict enhancing, so more trade with increased exports by both sides to each other should be encouraged. More access to Pakistani markets on the Indian side may not lead to conflict mitigation if Pakistan is not able to also export more to India. A rise in education expenditure puts a check on hostilities, as seen in Graph 1e. Graph 1f is the standard representation of India-Pakistan conflict, and not only best fits historical trends but also explain the rationale behind recent IndiaPakistan peace initiatives with decreasing hostilities when not only India but Pakistan also has had economic growth rates as high as $7 \%$ per annum. The forecasts suggest that conflict will rise, even if there is a significant increase in combined democracy scores, if growth rates plummet. Both Pakistan and India have seen many such years, when hostilities between both countries rose significantly when at least one of the countries is performing poorly, but were channeling more resources on the military as 
a proportion of their GDPs. The forecasts favour the economic version over the democratic version of the liberal peace. Thus one may look at current peace talks between both countries with optimism as both are performing well on the economic front and channeling fewer resources on the military as a proportion of national income, while at the same time having a divergent set of political institutions, though recently Pakistan has edged towards greater democracy with elections in February 2008.

A more detailed way to further gauge the dynamics of the relationship between conflict and trade is through the examination of Impulse Response Function (IRF) and Forecast Error Variance Decomposition (FEVD). IRFs describe the effect of exogenous impulses on any set of endogenous variables, while FEVDs capture the forecast error variance for each variable that is attributable to its own innovation and to the innovation in other endogenous variables. To this purpose, we introduce a more comprehensive VECM equation (VECM7) where conflict is explained by multilateral trade, bilateral trade, economic growth, military expenditure and democracy simultaneously in one single equation:

$$
\begin{aligned}
\operatorname{Conf}_{4 t}= & \alpha_{4}\left(\beta_{19, t-i} \operatorname{Conf}_{t-i}+\beta_{20, t-i} \text { Ptr }_{t-i, \text { multilateraltrade }}\right. \\
& +\beta_{21, t-i} \text { Ptr }_{t-i, \text { bilateraltrade }}+\beta_{22, t-i} \text { Itr }_{t-i, \text { multiltarealtrade }} \\
& +\beta_{23, t-i} \text { Itr }_{t-i, \text { bilateraltrade }} \\
& +\beta_{24, t-i} \operatorname{Pgpc}_{t-i}+\beta_{25, t-i} \text { IgPc }_{t-i}+\beta_{26, t-i} \text { Pdg } g_{t-i}+\beta_{27, t-i} \text { Idg }_{t-i} \\
& \left.+\beta_{28, t-i} \text { Demo }_{t}\right)+\sum_{y=1}^{10} C_{y d, t-i}+\mathrm{E}_{4 t} \ldots
\end{aligned}
$$

Table 3 provides the IRF and FEVD results for Eq. 15. A positive shock in overall global trade levels in Pakistan would lead to a decrease in fatality levels. The conflict mitigating effect of trade does not subside for long. By contrast, a positive shock in Indian overall trade raises fatality levels. Any positive shock in Pakistan' exports to India would increase the possibility of a further rise in hostilities, but if Pakistan raises its imports from India that may neutralise such negative shocks. In estimating the earlier Eqs. 12, 13 and 14, we found that higher exports to India by Pakistan may not lead to easing of tensions between both neighbours while Indian exports to Pakistan are more closely related with conflict mitigation between both sides. Recently, both sides have utilised bilateral trade as a measure to abate hostility. Pakistan in 2006 unilaterally opened up its borders to Indian goods as part of the peace strategy initiated by former Pakistani President Pervez Musharraf.

Better economic performance by Pakistan may abate hostilities between both nations as any positive shock in Pakistani growth rates cause fatality scores to move downwards. However, in Indian case this does not seem to be happening since results show that shocks in Indian growth rate are positively related with Fatal. Similarly, Pakistani defence expenditure is negatively related with Fatal, and Indian defence expenditure is positively related to it. A positive shock in Pakistani military expenditure would abate conflict, while a similar shock in Indian military expenditure has an opposite effect on conflict. The size of IRF coefficients for Idg in comparison to Pdg suggests that Indian military expenditure is more closely related with conflict, while 
Table 3 IRFs and FEVDs for fatal

VECM 7: Fatal, Popen, Iopen, Pxi, Ixp, Pgpc, Igpc, Pdg, Idg, Demopi

\begin{tabular}{|c|c|c|c|c|c|}
\hline \multicolumn{6}{|l|}{ Respor } \\
\hline \multirow[b]{2}{*}{ Period } & \multicolumn{5}{|l|}{ Impulse variables } \\
\hline & Popen & Iopen & Pxi & Ixp & Pgpc \\
\hline 1 & $-0.0473(0.000)$ & $0.2413(0.000)$ & $0.0130(0.000)$ & $0.0026(0.000)$ & $-0.1217(0.000)$ \\
\hline 2 & $-0.0644(0.032)$ & $0.3089(0.006)$ & $0.0005(0.017)$ & $-0.3191(0.000)$ & $-0.1635(0.002)$ \\
\hline 3 & $-0.0531(0.036)$ & $-0.2347(0.032)$ & $0.0070(0.012)$ & $-0.3537(0.002)$ & $-0.1155(0.002)$ \\
\hline 4 & $-0.0629(0.041)$ & $0.2555(0.033)$ & $0.0035(0.014)$ & $-0.0651(0.006)$ & $-0.0977(0.003)$ \\
\hline 5 & $-0.0511(0.042)$ & $0.2132(0.036)$ & $0.0064(0.012)$ & $-0.2043(0.005)$ & $-0.0878(0.003)$ \\
\hline 6 & $-0.0582(0.043)$ & $0.2380(0.035)$ & $0.0054(0.012)$ & $-0.1730(0.006)$ & $-0.1280(0.003)$ \\
\hline 7 & $-0.0574(0.045)$ & $0.2490(0.036)$ & $0.0047(0.011)$ & $-0.2334(0.005)$ & $-0.1091(0.003)$ \\
\hline 8 & $-0.0571(0.045)$ & $0.2350(0.037)$ & $0.0056(0.010)$ & $-0.1861(0.005)$ & $-0.1092(0.003)$ \\
\hline 9 & $-0.0569(0.046)$ & $0.2381(0.037)$ & $0.0050(0.010)$ & $-0.1865(0.005)$ & $-0.1074(0.002)$ \\
\hline 10 & $-0.0566(0.047)$ & $0.2362(0.037)$ & $0.0055(0.009)$ & $-0.1958(0.005)$ & $-0.1097(0.002)$ \\
\hline Period & Igpc & Pdg & Idg & Demopi & Fatal \\
\hline 1 & $0.1654(0.000)$ & $0.2458(0.000)$ & $0.5649(0.000)$ & $0.0012(0.000)$ & $0.4012(1.000)$ \\
\hline 2 & $0.1143(0.050)$ & $-0.5017(0.034)$ & $1.1441(0.002)$ & $-0.0006(0.006)$ & $0.7459(0.864)$ \\
\hline 3 & $0.1796(0.047)$ & $-0.1098(0.030)$ & $0.7268(0.022)$ & $-0.0004(0.007)$ & $0.6468(0.798)$ \\
\hline 4 & $0.1014(0.065)$ & $-0.1325(0.028)$ & $1.0022(0.020)$ & $-0.0002(0.011)$ & $0.6710(0.769)$ \\
\hline 5 & $0.1362(0.062)$ & $-0.0899(0.025)$ & $0.7309(0.022)$ & $0.0000(0.012)$ & $0.6843(0.773)$ \\
\hline 6 & $0.1268(0.064)$ & $-0.1573(0.024)$ & $0.8975(0.020)$ & $-0.0003(0.012)$ & $0.6304(0.775)$ \\
\hline 7 & $0.1361(0.064)$ & $-0.1690(0.024)$ & $0.8687(0.020)$ & $-0.0002(0.012)$ & $0.6814(0.772)$ \\
\hline 8 & $0.1314(0.066)$ & $-0.1339(0.023)$ & $0.8580(0.020)$ & $-0.0002(0.012)$ & $0.6576(0.770)$ \\
\hline 9 & $0.1286(0.067)$ & $-0.1404(0.023)$ & $0.8617(0.020)$ & $-0.0002(0.013)$ & $0.6666(0.769)$ \\
\hline 10 & $0.1318(0.067)$ & $-0.1406(0.023)$ & $0.8515(0.020)$ & $-0.0002(0.013)$ & $0.6619(0.769)$ \\
\hline
\end{tabular}

FEVDs in parentheses

Pakistani military expenditure may represent an element of deterrence. Democracy is good for peace, but the effect is minimal. An overview of the evolution of shocks over time for Fatal in Eq. 15 is presented in Fig. 7. We can see that in the short run, conflict captured by fatality levels has been most sensitive to military expenditures in India and Pakistan. Any positive shock in Indian or Pakistani military expenditure would exert upward pressure on fatality levels in the short run, but within the 3rd-4th year the nature of this effect transforms into a nonlinear relationship between conflict and military burden, where fatality levels would be rising steeply as an outcome of a positive shock in Indian military expenditure, while fatalities would witness a drop when the shock emanates from Pakistan. In the long run however, the shock originating from the Pakistani side would be absorbed and the fatality levels would adjust to their original level, while fatality levels would adjust to higher values when the shock emanates from the Indian side. Table 3 also shows that FEVD is the highest for Fatal itself, suggesting that current variations in fatality levels are highly dependent on their previous values. 

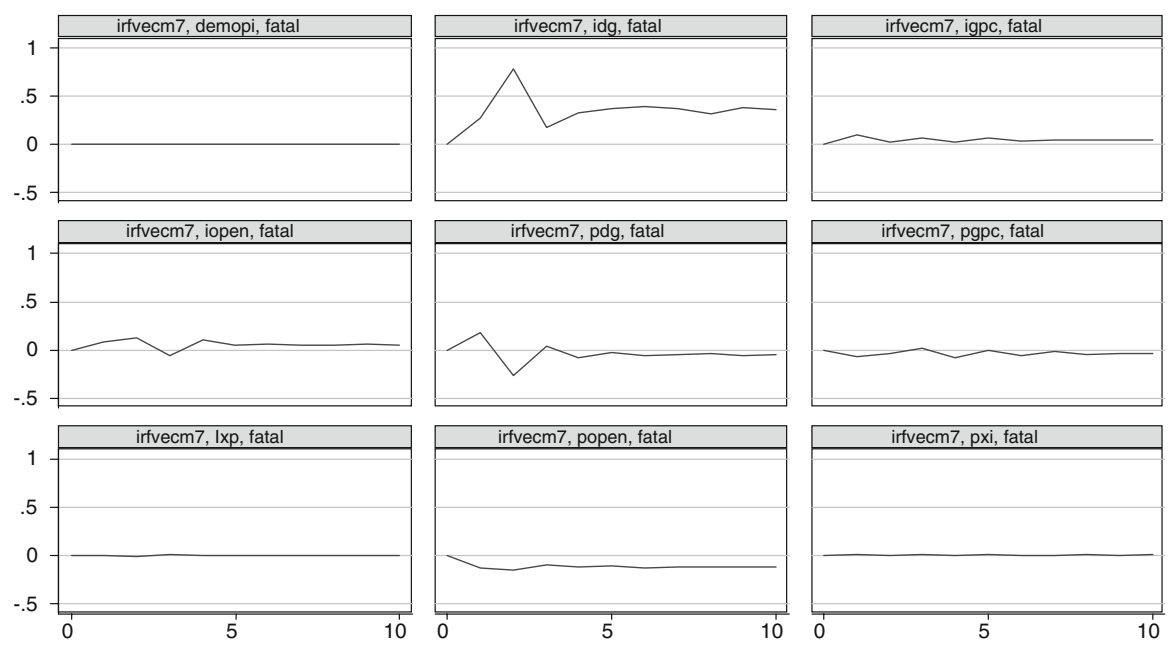

Fig. 7 VECM7 IRFs for fatal
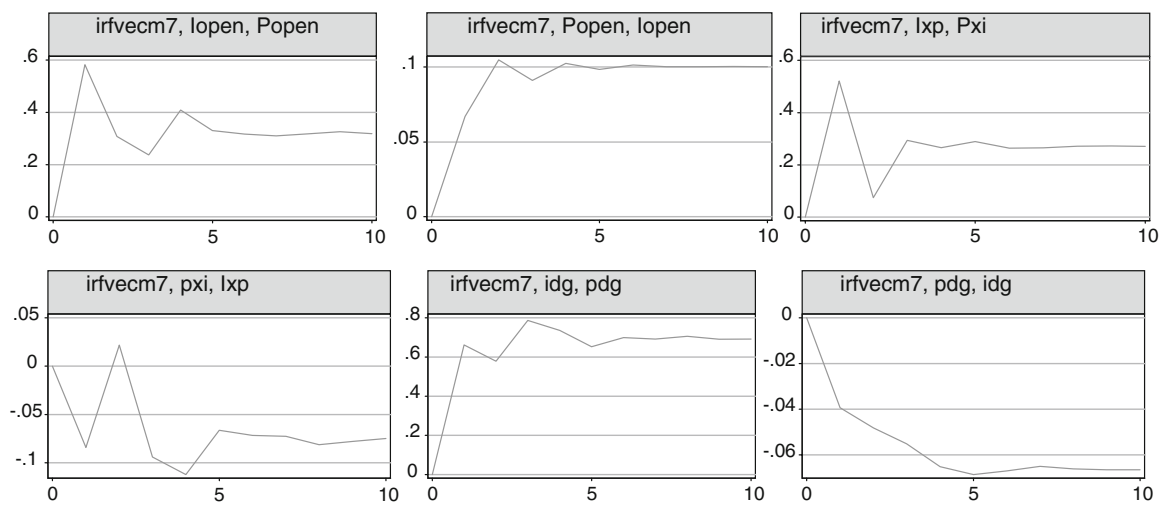

Fig. 8 Trade and military dynamics of conflict

Figure 8 shows some more IRFs based on VECM7 plotting reactions of rival parties' multilateral, bilateral trade and military expenditure when shocks are induced in these variables for any one country. For example, a positive shock in Indian trade with the rest of the world would also improve the trading capacity of Pakistan and vice versa. However, trade levels would settle down at higher levels in case the shock is induced from Pakistan. If Indian exports to Pakistan rise, Pakistan will also be able to export more to India while the inverse is not true. If Pakistan is able to export more to India, the competitiveness of Indian exports to Pakistan decline. A positive shock in Indian defence expenditure would induce a similar response in Pakistan's defence expenditure and vice versa providing further suggesting that Pakistani military expenditures are more reactionary to Indian military postures and represent deterrence than hostility, unlike in the Indian case. 


\section{Conclusions}

Conflict between India and Pakistan, which spans over most of last 60 years since their independence from British rule, has significantly hampered bilateral trade between the two nations. However, we also find that the converse is also true; more trade between India and Pakistan (especially Indian exports to Pakistan) decreases conflict and any measures to improve the bilateral trade share is a considerable confidence building measure. A regional trade agreement along the lines of a South Asian Free Trade Agreement (SAFTA) has much potential for the improvement of relations between India and Pakistan on a long-term basis. Pakistan and India's general degree of openness to world trade is, however, the dominant economic factor in conflict resolution, as argued by Dorussen and Ward (2010).

We find some evidence that India's military expenditure is conflict enhancing, whereas Pakistan's is more reactive. In an ideal world increased dyadic democracy between pairs of nation should reduce inter-state hostility according to the democratic liberal peace hypothesis; this relationship in our case is present but weak. Peace initiatives, it should be remembered, are not the sole prerogative of democracies; they can also be made by countries which are less than perfectly democratic out of economic self-interest. Pakistan, at present, is making unilateral concessions on many disputed issues with India. Our findings, however, veer towards the economic variant of the liberal peace hypothesis. Economic progress (especially in Pakistan) and poverty reduction combined with greater openness to international trade in general are more significant drivers of peace between nations like India and Pakistan, rather than the independent contribution of a common democratic polity. Despite a relatively high democracy score in Pakistan up to 1999, conflict between the countries escalated in the 1990s. So it is more economic interdependence rather than politics which is likely to contribute towards peaceful relations between India and Pakistan in the near future. In many ways, our results for an individual dyad echo Polachek (1997) work across several dyads, where it is argued that democracies cooperate not because they have common political systems, but because their economies are intricately and intensively interdependent. As pointed by Hegre (2000), it is at these higher stages of economic development that the contribution of common democratic values to peace becomes more salient. Meaningful democracy cannot truly function where acute poverty is endemic, even in ostensible democracies such as India. In the final analysis, it may be that democracy itself is an endogenous by-product of increased general prosperity, as suggested nearly half a century ago by Lipset (1960). Only then, will nations be able to fully appreciate Angell-Lane (1910) arguments regarding the futility of conflict.

\section{Appendix: data and sources}

Demopi: Pakistan and India's combine democracy score (by adding 10 to India and Pakistan's Polity2 values for each year and then taking the product of these values in order to covert the variable in dyadic form), Years; 1950-2003

Fatal: Annual fatality level of conflict between Pakistan and India, scores from 0 to 6 

0 None
1 1-25 Deaths
2 26-100 Deaths
3 101-250 Deaths
4 251-500 Deaths
5 501-999 Deaths
6>999 Deaths

Years: 1950-2003, Source: COW Inter-State War Data, Version 3.02, Faten et al. (2004)

Idg: India's Defence Expenditure as a percentage India's GDP at current market prices, Years: 1950-2005, Sources: Correlates of war data set version 3.02, World Development Indicators (2006) (World Bank), Government Finance Statistics Year Book 2006 (IMF) and Economic Survey of Pakistan

Iedug: India's education expenditure as a \%age of India's GDP at current market prices, Years: 1950-2005, Sources: Indian Economic Survey, Education Statistics (Department of Education, India) and Education Statistics 2006 (World Bank)

Iexpg: India's total exports as a percentage of India's GDP, Years: 1950-2005, Source: Indian Economic Survey, International Financial Statistics (2006) (IMF)

Ig: Annual growth rate of India's per capita gross domestic product (GDP) at constant prices, Years: 1950-2005, Source: Indian Economic Survey

Igpc: India's real per capita growth rate: Years: 1950-2005, Source: Indian Economic Survey, International Financial Statistics (2006)(IMF), World Development Indicators (2006) (World Bank)

Iimpg: India's total imports as a percentage of India's GDP, Years: 1950-2005, Source: Indian Economic Survey, International Financial Statistics (2006) (IMF)

Imilopop: India's number of military personnel as a percentage of Indi's total population. Years: 1950-2003, Source: COW Inter-State War Data, Version 3.02, Faten et al. (2004); International Financial Statistics (2006) (IMF)

Iopen: India's exports plus imports as a \%age India's GDP at current market prices, Years: 1950-2005, Source: International Financial Statistics (2006) (IMF)

Ixp: Indian exports to Pakistan, Years: 1960-2005, Source: as above.

P2i: Polity 2 Score for India, numeric range from -10 (high autocracy) to 10 (high democracy), Years: 1950-2003, Source: Polity IV Project(Center for International Development and Conflict Management)

P2p: Polity 2 Score for Pakistan, numeric range from -10 (high autocracy) to 10 (high democracy), Years: 1950-2003, Source: as above.

Pedug: Pakistan's education expenditure as a percentage of Pakistan's GDP at current market prices, Years: 1950-2005, Sources: Pakistan Economic Survey and Education Statistics 2006 (World Bank)

Pexpg: Pakistan's exports as a percentage of Pakistan's GDP, Years: 1950-2005, Source: International Financial Statistics 2006 (IMF) 
Pdg: Pakistan's Defence Expenditure as a percentage Pakistan's GDP at current market prices, Years: 1950-2005, Sources: Correlates of war data set version 3.02, World Development Indicators (2006), Government Finance Statistics Year Book 2006 (IMF) and Economic Survey of Pakistan

Pg: Annual growth rate of Pakistan's GDP per capita at constant prices, Years: 1950-2005, Source: Pakistan Economic Survey

Pgpc: Pakistan's real GDP per capita Growth rates, Years: 1950-2005, Source: International Financial Statistics (2006) (IMF), Pakistan Economic Survey

Pimpg: Pakistan's imports as a percentage of Pakistan's GDP, Years: 1950-2005, Source: International Financial Statistics (2006) (IMF)

Pmilpop: Pakistan's number of military personnel as a percentage of Pakistan's total population. Years: 1950-2003, Source: COW Inter-State War Data, Version 3.02, Faten et al. (2004); International Financial Statistics (2006) (IMF)

Popen: Pakistan's exports plus imports as a percentage Pakistan's gross domestic product at current prices, Years: 1950-2005, Source: International Financial Statistics (2006) (IMF)

Pxi: Pakistan's exports to India, Years: 1960-2005, Source: Direction of Trade Statistics yearbook, IMF

Acknowledgments We wish to thank participants of the WZB workshop (Berlin, 28-29th March 2008), the guest editor of this issue (Stergios Skaperdas), and an anonymous referee for helpful comments.

Open Access This article is distributed under the terms of the Creative Commons Attribution Noncommercial License which permits any noncommercial use, distribution, and reproduction in any medium, provided the original author(s) and source are credited.

\section{References}

Angell-Lane RN (1910) The great illusion: a study of the relation of military power in nations to their economic and social advantage. Heinemann, London

De Montesquieu CL (1748) De l'Espirit des Lois. reprinted, Flammarion, Paris, 1979

Deger S, Sen S (1990) Military security and the economy: defence expenditure in India and Pakistan. In: Hartley K, Sandler T (eds) The economics of defence spending. Routledge, London, pp 189-227

Dorussen H, Ward H (2010) Trade networks and the Kantian peace. J Peace Res. forthcoming

Gartzke E (2007) The capitalist peace. Am J Pol Sci 51(1):166-191

Ghosn F, Palmer G, Bremer S (2004) The MID3 data set, 1993-2001: procedures, coding rules, and description. Confl Manag Peace Sci 21:133-154

Gleditsch NP (2008) The liberal moment fifteen years on. Int Stud Q 15(4):691-712

Granger C (1969) Investigating causal relations by econometric models and cross-spectral methods. Econometrica 37:424-438

Harbom L, Högbladh S, Wallensteen P (2006) Armed conflict and peace agreements. J Peace Res 43(5):617-631

Hegre H (2000) Development and the liberal peace: what does it take to be a trading state. J Peace Res 37(1):5-30

International Financial Statistics (2006) International monetary fund. Washington, DC

Kant I (1795) Perpetual peace and other essays on politics, history and morals, reprinted 1983, Hackett Publishing, Indianapolis

Kim HM, Rousseau DL (2005) The classical liberals were half right (or half wrong): new tests of the 'liberal peace', 1960-1988. J Peace Res 42(5):523-543

Lipset S (1960) Political man: the social bases of politics. Doubleday, New York

McDonald Patrick J (2004) Peace through trade or free trade?. J Conflict Resolut 48(4):547-572 
Murshed SM (2010) Explaining civil war: a rational choice approach. Cheltenham, Edward Elgar

Murshed SM, Mamoon D (2007) On the costs of not loving thy neighbour as thyself: the trade, democracy and military expenditure explanations behind India-Pakistan Rivalry', ISS Working paper no. 446, www.iss.nl

Polachek SW (1997) Why democracies cooperate more and fight less: the relationship between international trade and cooperation. Review of Int Econ 5(3):295-309

Polachek SW, Seiglie C (2006) Trade, peace and democracy: an analysis of dyadic dispute, IZA DO No. 2170

Polity IV Project (Center for International Development and Conflict Management), http://www.cidcm. umd.edu/polity

Sims C (1980) Macroeconomics and reality. Econometrica 48:1-48

World Development Indicators (2006) World bank. Washington, DC 